JURNAL TEKNOLOGI DAN OPEN SOURCE

Vol. 4, No. 1, June 2021, pp. 28 36

e-ISSN: 2622-1659, accredited Four Grade by Kemenristekdikti, Decree No: 36/E/KPT/2019

DOI: $10.36378 /$ jtos.v4i1.1313

\title{
DESIGN OF MANAGEMENT INFORMATION SYSTEM OF FINAL ASSIGNMENT GUIDANCE (SIMBITA) WEB-BASED
}

\author{
Eko Haryadi ${ }^{1)}$, Diah Wijayanti²) Dewi Yuliandari ${ }^{3)}$, Syafrianto ${ }^{4)}$ Asep Bambang ${ }^{5)}$ \\ 1,2,3,5 Teknik\&Informatika,Universitas Binasarana Informatika PSDKU Karawang, Jalan Banten No.1 Karangpawitan \\ Karawang
}

${ }^{4}$ Sistem Informasi, STMIK Nusa Mandiri Jl. Raya Jatiwaringin No.18, RT.009/RW.005, Jaticempaka, Kec. Pondokgede, Kota Bks, Jawa Barat

\begin{tabular}{l}
\hline \hline Article Info \\
\hline Article history: \\
Received 04 April, 2021 \\
Revised 09 June, 2021 \\
Accepted 09 June, 2021 \\
\hline
\end{tabular}

\section{Keywords:}

Management

Information System

Final Assigment

\begin{abstract}
The implementation of guidance in two directions is carried out by discussing, conducting questions and answers, providing input and other activities. However, sometimes the guidance process carried out face-to-face experiences many obstacles so the coaching process does not run optimally and it is not as expected. The most common obstacle is when the supervisor is unable to attend the final assignment guidance. Communication barriers between students and supervisors also affect the success of the final assignment. Hence, it is necessary to develop a way to have the obstacles can overcome better. The method used to solve these problems using the system development life cycle method. The solution is currently using sms or online facilities such as email, social media, or the cloud from a third party. With this system, if face-to-face guidance activities are not possible, the process of preparing student final assignments can be carried out in order to be on time for the graduation of students in the institutions.
\end{abstract}

This is an open access article under the $\underline{C C B Y-S A}$ license.

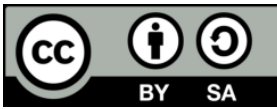

\section{Corresponding Author:}

Eko Haryadi

Teknik\&Informatika,Universitas Binasarana Informatika PSDKU Karawang

Jalan Banten No.1 Karangpawitan Karawang

Email: eko.ehy@bsi.ac.id

(c) Eko Haryadi 2021

\section{Introduction}

The current technological development is so fast and it is very important to support human activities in order to optimize time better. One example of technology helps human activities is information systems. [1] "An information system is a system within an organization that meets the needs of data management, supports operations, managerial and strategic activities of an organization or agency and provides reports for certain parties. Education institutions need information systemto support in improving the quality of services to the education process. Such as an academic information system which consists of many processes, including lecture planning to the final process such as the preparation of student final assignments. [2] "The final project/assignment is a scientific paper on research that discusses a problem in a particular field of science by using applicable scientific principles. Apart from being a graduation requirement, this final assignment aims to enable students to compile and write a scientific paper in accordance with their field of knowledge in understanding, analyzing, explaining problems and providing solutions in accordance with the field of science 
they are taking ". This final project also in knowing the ability of students, whether they mastered the knowledge was given and able to apply the knowledge in society according to the competencies".

The final assignment guidance system is currently still running carried out by meeting directly between students and their supervisors. In practice, this final assignment guidance activity is carried out with discussion, question and answer, giving input and other activities. However, sometimes the guidance process carried out face-toface experiences have many obstacles so that the guidance process does not run optimally and it is not as expected. The most common obstacle faced is when the supervisor is not in place, moreover, a supervisor on average supports more than 10 students and each student generally does not have a regular schedule in conducting guidance so that if you want to attend, you have to queue physically. Communication constraints between students and supervisors also affect the success of the final project. The current solution is by utilizing sms or online facilities such as email, social media, or the cloud from a third party. Apart from that, there are other obstacles that make face-to-face guidance impossible, but the process of preparing student final assignments must continue in order to catch up on timeliness and student graduation in tertiary institutions.

\section{Research Methods}

Web-based learning as known as web-based processing (WBT) or web-based education (WBE) can be defined as the application of web technology in the world of learning for an educational process. In simple terms it can be said that all learning by utilizing internet technology [3] web-based learning is learning activity by using website and internet network "[4] Web-based learning media or e-learning is one of media learning used by the teacher on teaching learning process now because of its flexibility and effectiveness in a way of delivering learning materials via the internet that can be accessed anytime and anywhere" [4]. According to Mardi in [5] explains that, "Information is processed data tobe more useful and more meaningful for those who receive it, describes an occurs (event), and real unity (fact and entity) and is used for decision making"

According to Darmawan and Fauzi in [6] "Information is processing data into a meaningful form for the recipient and is useful in making decisions at present or in the future". Agus Mulyanto stated in [7] that "Information is data had been processed into a form tobe more useful and more meaningful to those who receive it, whereas the data is a source of information that describes a real event". Management is a typical process that consists of actions: planning, organizing, mobilizing and controlling carried out to determine and achieve predetermined goals through the use of human resources and other sources [8]. The final assignment is a final project that must be completed by a student who will graduate from a bachelor's degree or diploma in a university or intitution "[9].

"The final project/assignment or thesis is a scientific paper on research that discusses a problem in a particular field of science by using applicable scientific principles" [4]. Regulation of the Minister of National Education of the Republic of Indonesia No.17 of 2010, No.6 "The final project is the academic work of students in the an institution in written form, both printed and electronic, published and / or presented" [10].

According to [11] the waterfall model is the simplest SDLC (Software Development Life Cycle) model. This model is only suitable for software development with unchanging specifications. The function of each part of the waterfall model is as follows:

1. Needy Analysis. This process that the authors prioritize the guidance and preparation process of students' final assignments. This is done to make eady for students and lecturer to carry out the guidance and preparation process of students' final assignments.

2. System and Software Design. At this step, the final project uses a database and UML models such as activity diagrams, usecase diagrams, class diagrams, sequence diagrams, entity relationship diagrams (ERD), and logical record structures (LRS).

3. Program Code making. Programming is a design translator in a language that can be recognized by the computer. In this process the author uses Sublime Text 3 software.

4. Testing. Testing focuses on the software both logically and functionally and ensures that all parts are tested. It was done to minimize errors and undetection errors. Testing on this website uses blackbox testing which involves system verification. Meanwhile, the implementation is done by implementing the localhost server.

5. Supporting or maintenance. It is possible that a software will change when it is sent to the user. Changes can occur due to errors and undetection during testing, or it can also happen that the software has to adapt to a new environment. This step can reduce the development process from the specification analysis step. 


\section{Results and Discussion}

\subsection{System design step}

\subsubsection{Needy Analysis}

Needy analysis is the first step to determine the resulting program. A good program according to user needs really depends on the success of conducting a needy analysis. There are two analyzes that are quite important to built a web, namely the analysis of user requirements and analysis of system requirements, as following:

a) User Requirements. In the Web-Based Final Project Guidance Management Information System, there are three users who can interact each other in the system environment, there are: admin, students and lecturer. The three users have interaction characteristics with different systems and have different information needs to manage student data

b) System Requirements. Users must log in first to access this website by entering their username and password so that the privacy of each user is maintained. Users must log out after using the web. Users can manage data on the web with access rights from that user.

\subsubsection{Use Case Diagram Design}

Use cases are described textually in the form of use case scenarios to explain the interactions that occur between actors and the system [12].

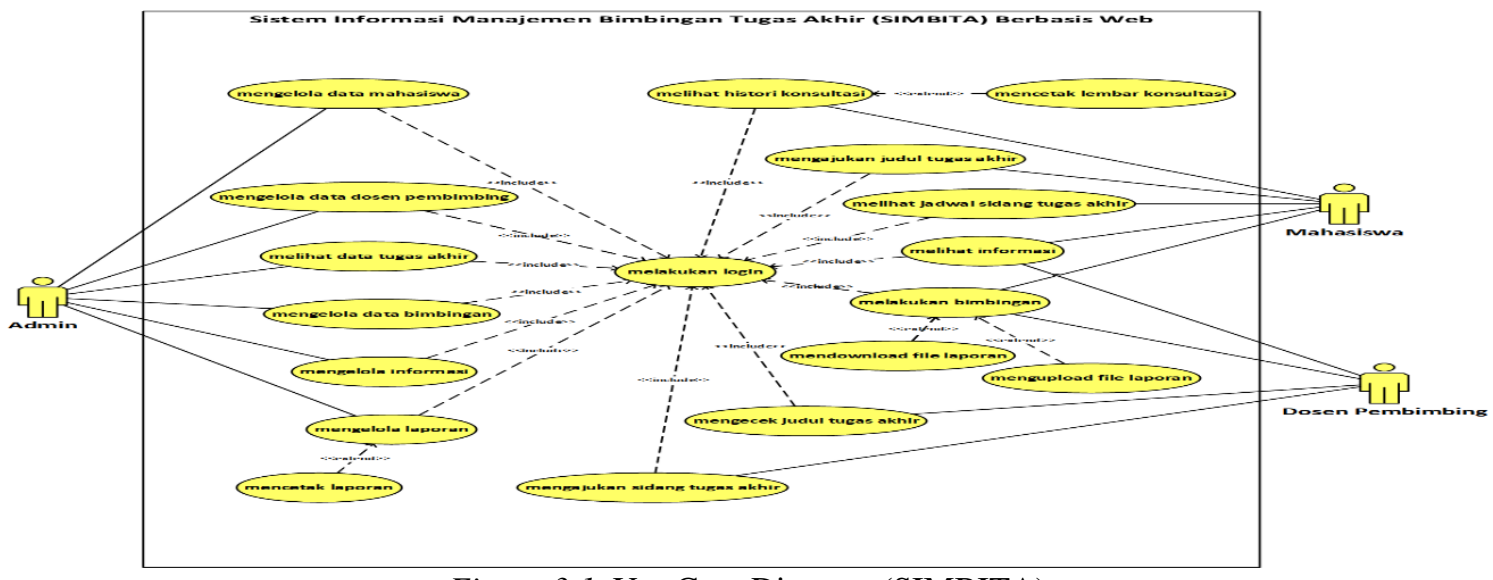

Figure 3.1. Use Case Diagram (SIMBITA)

Tabel 3.1.

Description of Use Case Login

Use Case Name Login

\begin{tabular}{ll}
\hline Requirements & User login \\
\hline Goal & User can login and can access website \\
\hline Pre-Conditions & User can input data login dan password \\
\hline Post-Conditions & User can access menu and website \\
\hline Failed end Condition & User cannot login \\
\hline Actors & Admin, Student, Lecturer \\
\hline Main Flow/ Basic Path & 1. User accesses login \\
& 2. User inputs data login and password \\
& 3. System processes login \\
& 4. System displays main menu of website \\
\hline
\end{tabular}

Alternate Flow/Invariant A

A1. System display main menu of website

Invariant B

B1. User acesses login

B2. User inputs data login and password

B3. System cannot process login

B4. System displays "Login failedl! Username or Password fault" 
Tabel 3.2.

Description of Use Case Mengelola Data Mahasiswa

\begin{tabular}{|c|c|}
\hline Use Case Name & Data of Students Process \\
\hline Requirements & Admin can process students data \\
\hline Goal & Admin processes students data via online into web \\
\hline Pre-Conditions & Admin login \\
\hline Post-Conditions & Adding students data \\
\hline Failed end Condition & Admin cannot process student data \\
\hline Actors & Admin \\
\hline Main Flow/ Basic Path & $\begin{array}{l}\text { 1. User login } \\
\text { 2. System displays dashboard page } \\
\text { 3. User chooses menu of students data } \\
\text { 4. System displays students data page } \\
\text { 5. User processes students data }\end{array}$ \\
\hline
\end{tabular}

\begin{tabular}{ll}
\hline Alternate Flow/Invariant A & A1. System displays students data page \\
\hline
\end{tabular}
Invariant B

Tabel 3.3.

Description of Use Case Mengel ola Data Dosen Pembimbing

\begin{tabular}{|c|c|}
\hline Use Case Name & Data of lecturers process \\
\hline Requirements & Admin can process lecturers data \\
\hline Goal & Admin processes lecturers data via online into web \\
\hline Pre-Conditions & Admin login \\
\hline Post-Conditions & Adding lecturers data \\
\hline Failed end Condition & Admin cannot process student data \\
\hline Actors & Admin \\
\hline Main Flow/ Basic Path & $\begin{array}{ll}\text { 1. } & \text { User login } \\
\text { 2. } & \text { System displays dashboard page } \\
\text { 3. } & \text { User chooses menu of lecturers data } \\
\text { 4. } & \text { System displays lecturers data page } \\
\text { 5. } & \text { User processes students data }\end{array}$ \\
\hline
\end{tabular}

\begin{tabular}{ll}
\hline Alternate Flow/Invariant A & A1. System displays lecturers data page \\
\hline Invariant B & -
\end{tabular}

\subsubsection{Activity Diagram Design.}

Activity diagram is a diagram can model the processes in management information systen of the final assignment guidance. The diagram activity shows system activity in the form of action collection, how each of these actions is begun, decisions occurs until the end of the action. [13]. 


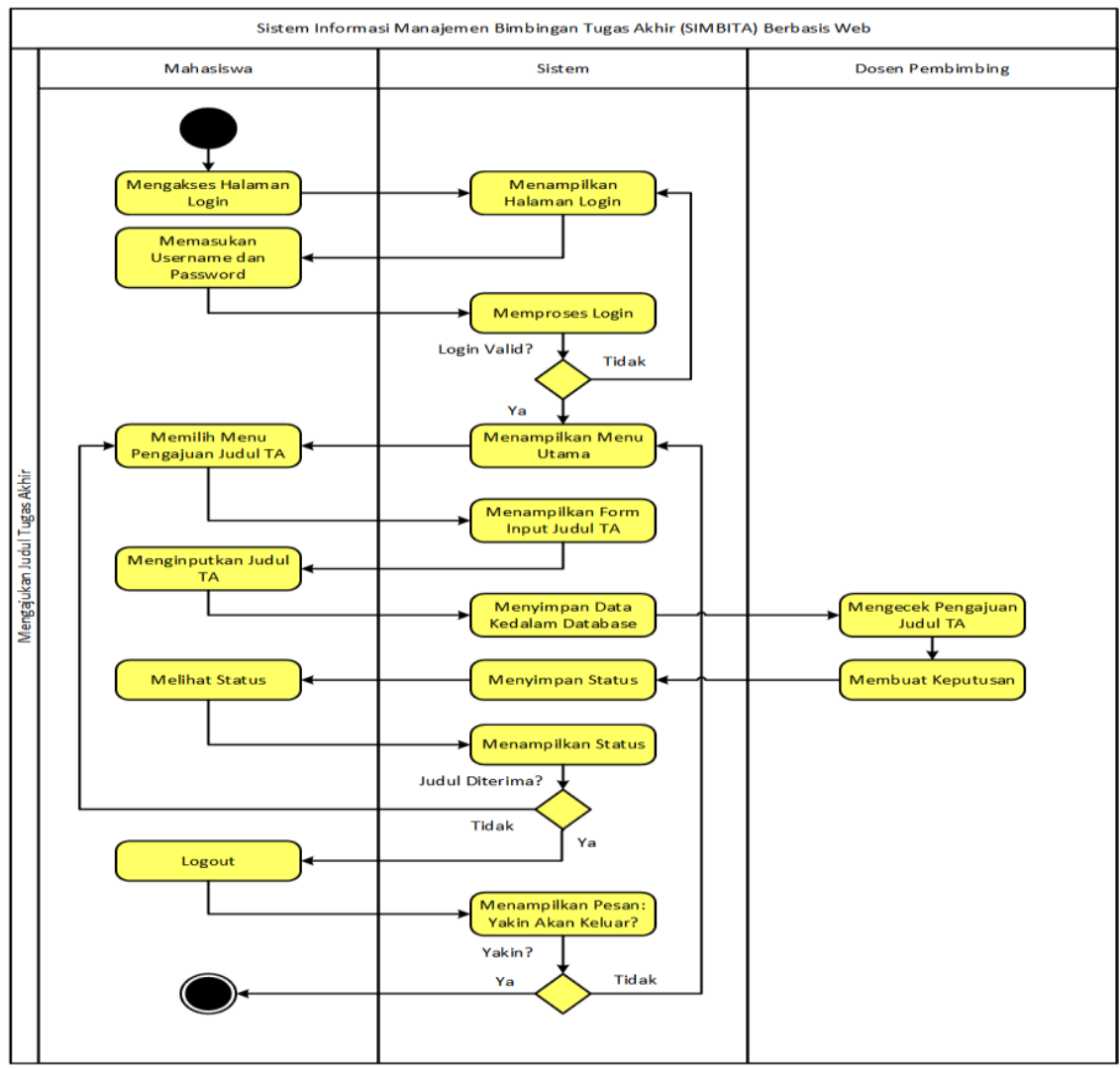

Figure 3.2. Rancangan Diagram Aktivitas SIMBITA

\subsubsection{Entity Relationship Diagram (ERD)}

In this section, the Entity relationship diagram or ERD is displayed diagram to describes the relationship between data objects and management information system of final assignment guidance. According to Brady and Loonam (2010) in [14], Entity Relationship Diagram (ERD) is a technique used to model the data needs of an organization, usually by System Analyst in the analysis step of system development project requirements.

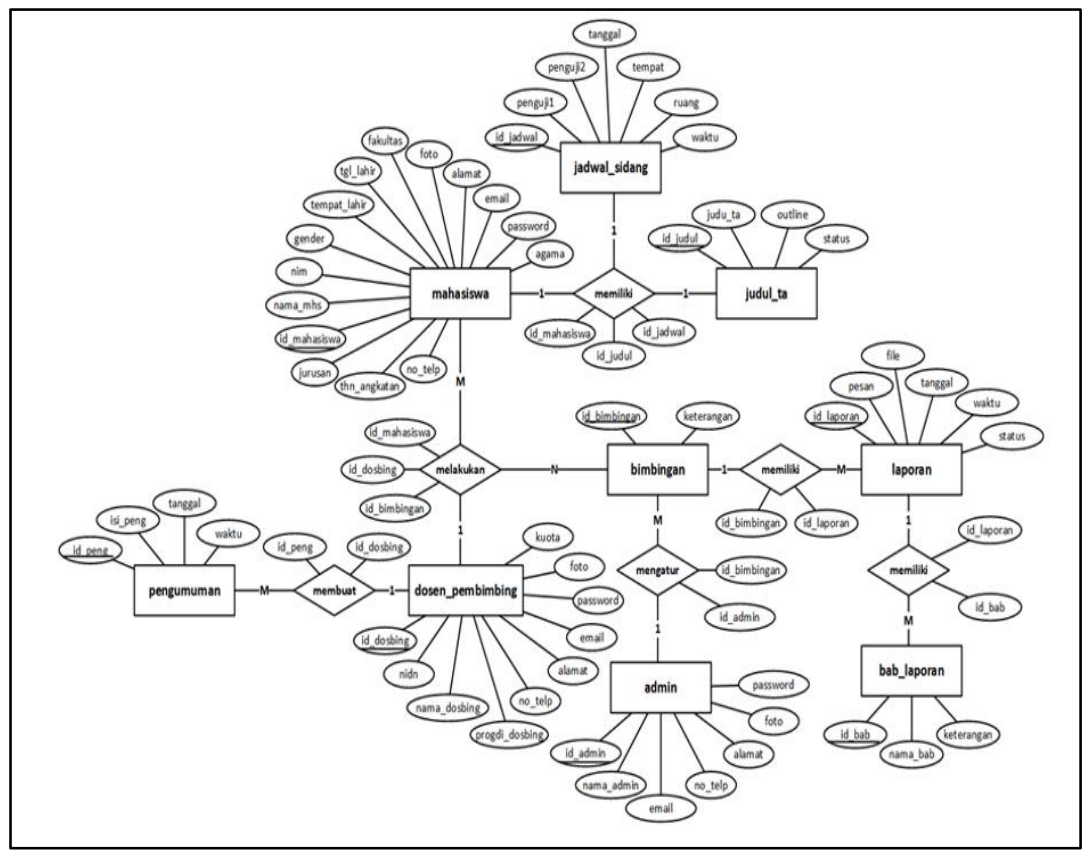

Figure 3.3. Entity Relationship Diagram (ERD) SIMBITA 


\subsubsection{Logical Record Structure (LRS)}

Logical Record Structure (LRS) is a representation of the structure of records in tables formed from the results of the relationship between the set of entities.

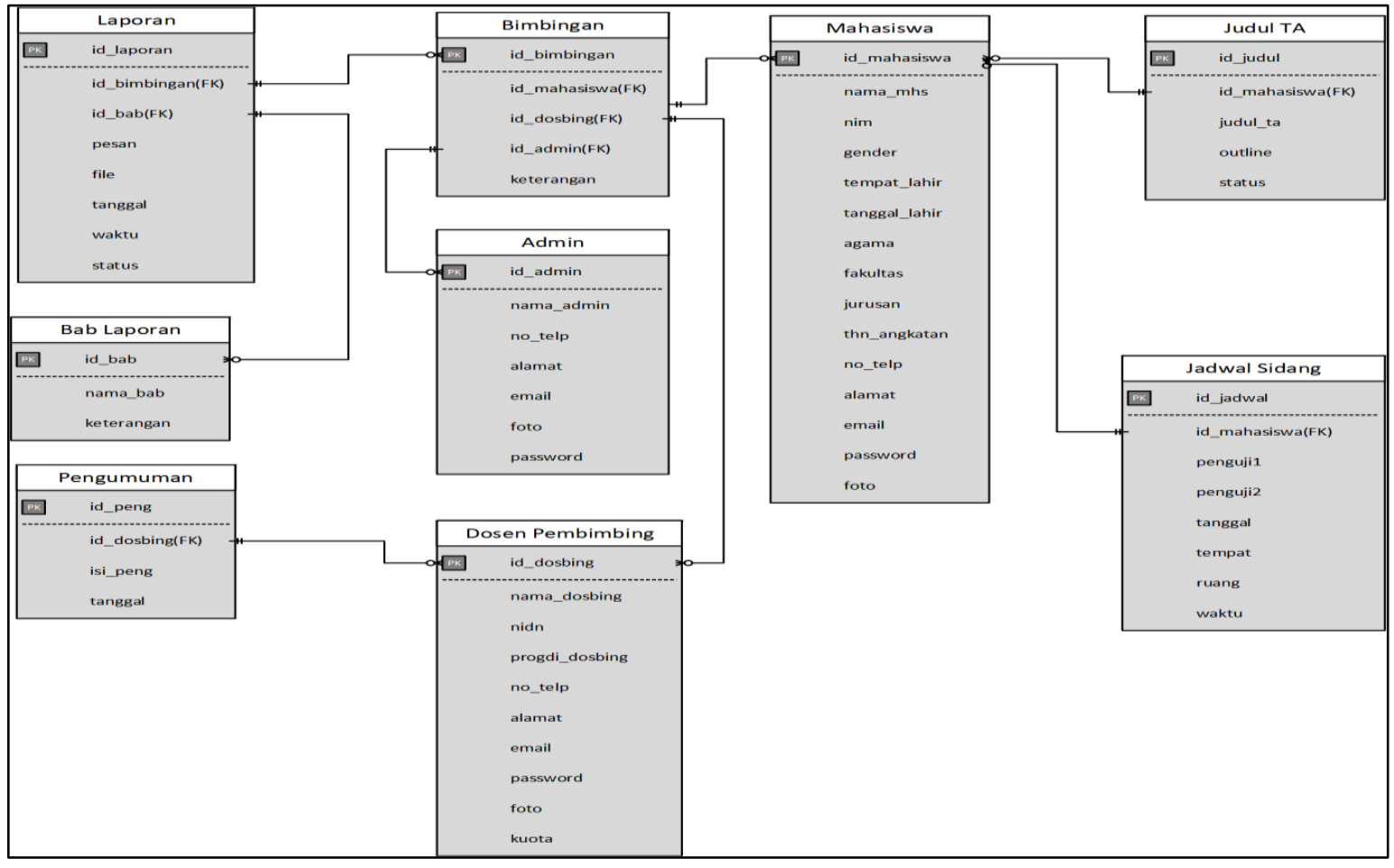

Figure 3.4. Logical Record Structure (LRS) SIMBITA

\subsubsection{Class Model or Class Diagram}

Class diagram is the relationship between classes and a detailed explanation of each class in the design model of a system, also shows the rules and responsibilities of entities to determine system behavior.

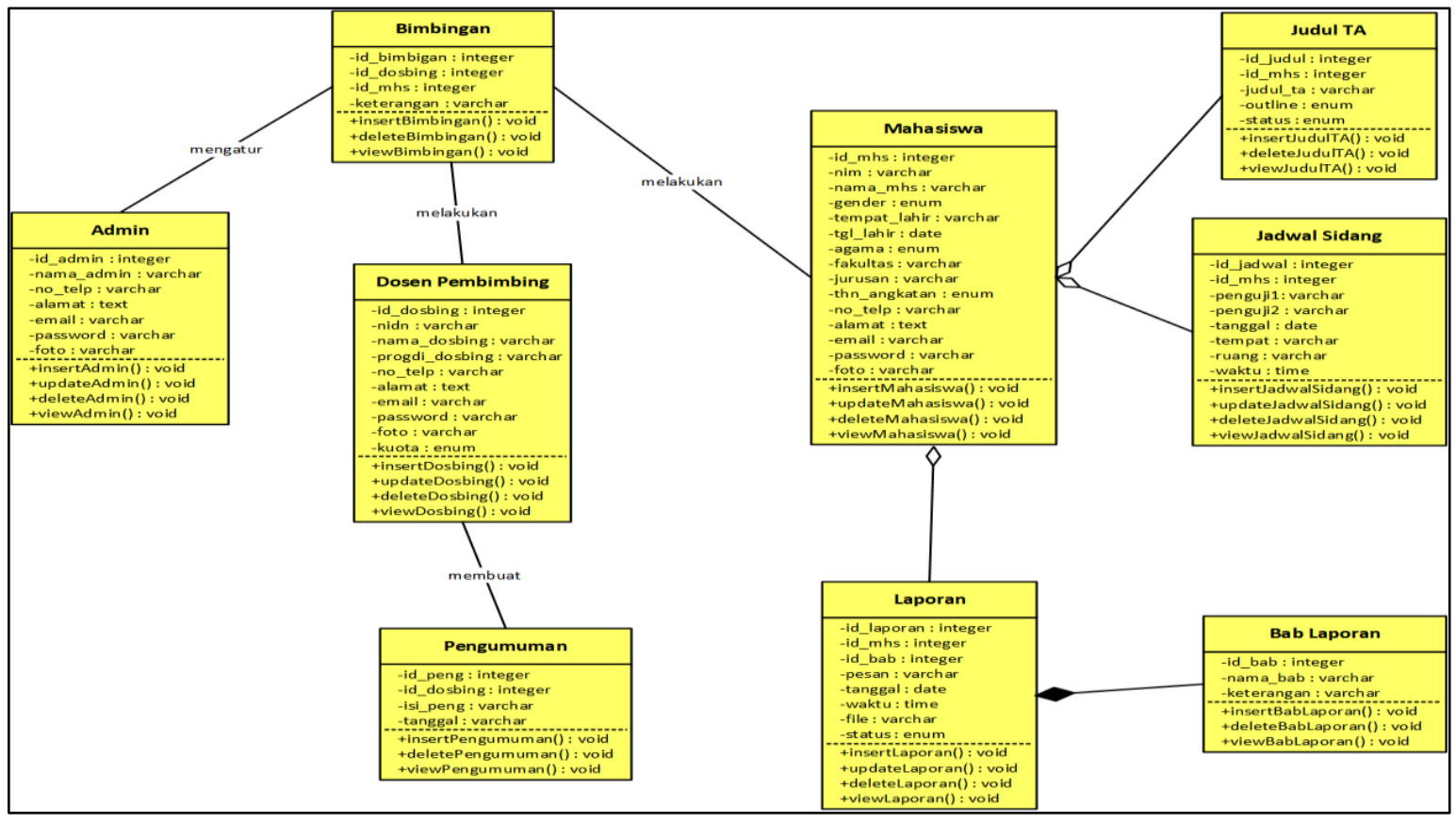

Figure 3.5. Class Model / Class Diagram SIMBITA 


\subsubsection{Sequence Diagram}

Sequence diagram is a diagram depicting dynamic collaboration between a number of objects in the Management Information System of final assignment guidance.

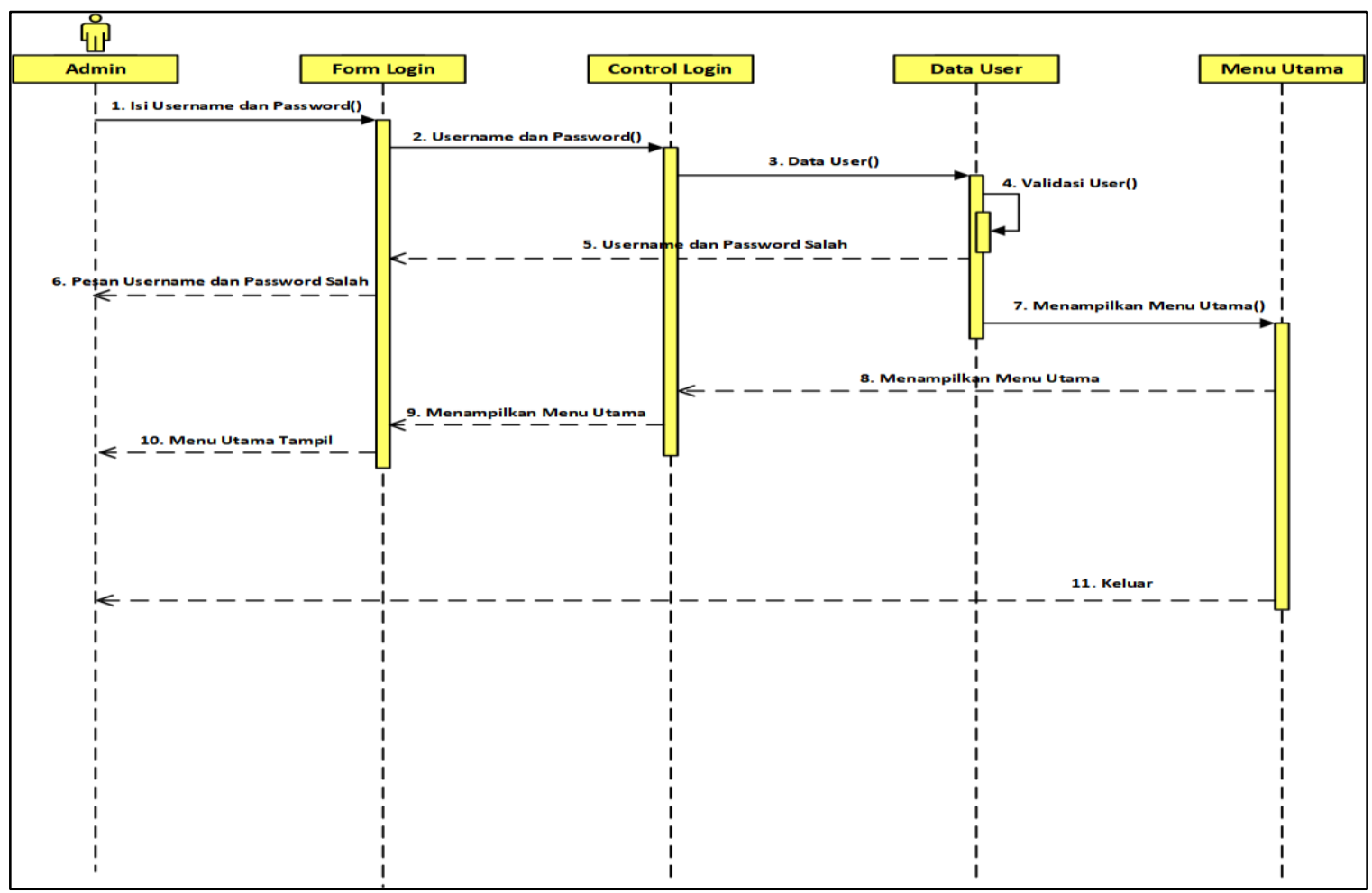

Figure 3.6. Sequence Diagram SIMBITA

\subsection{Display}

\subsubsection{Interface Login Admin}

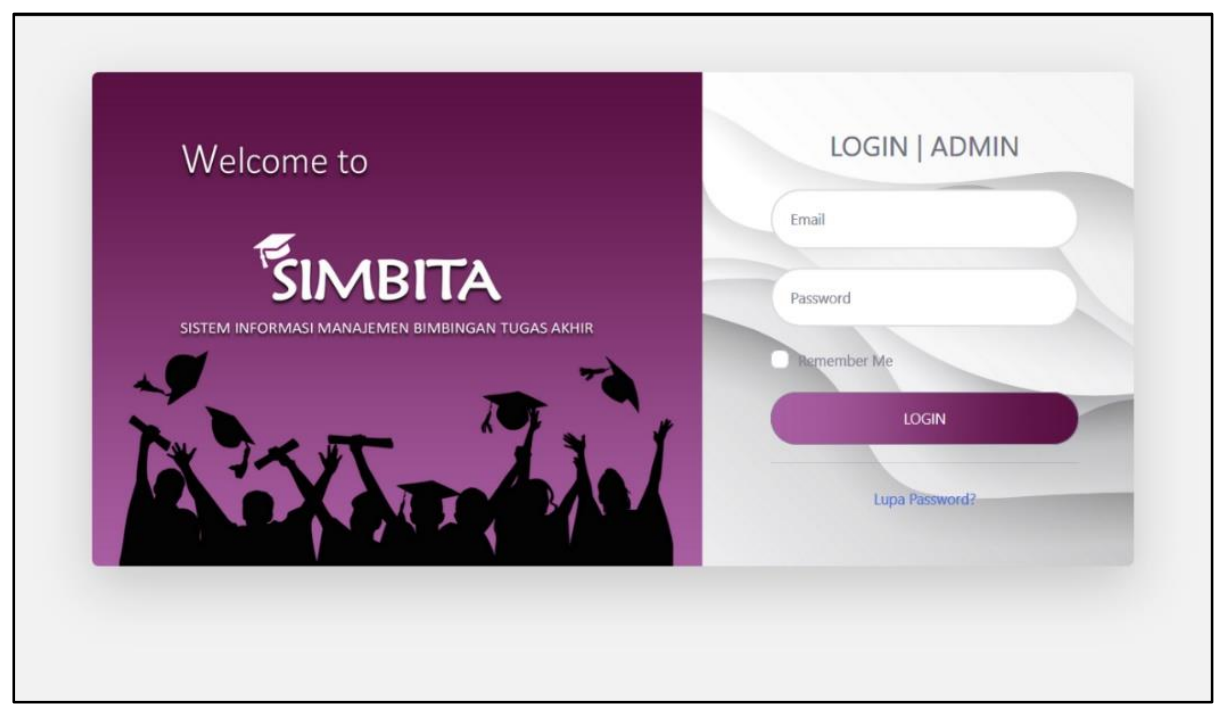

Figure 3.7. Interface Login Admin SIMBITA 


\subsubsection{Main Menu Admin}

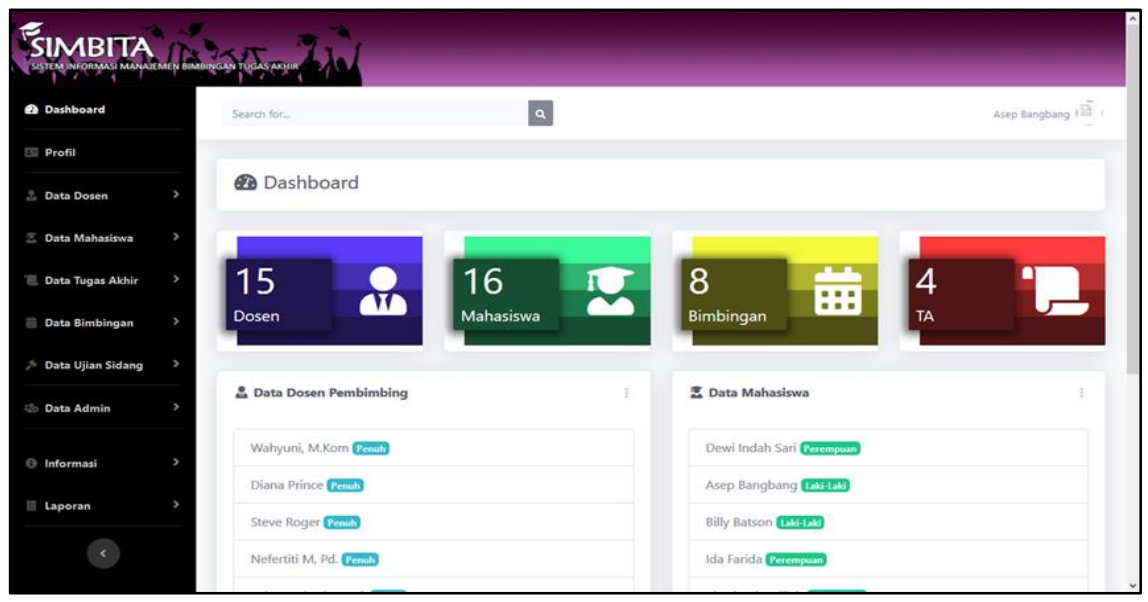

Figure 3.8 Мепи Utama Admin SIMBITA

\subsubsection{Menu Data Pengajuan Judul TA}

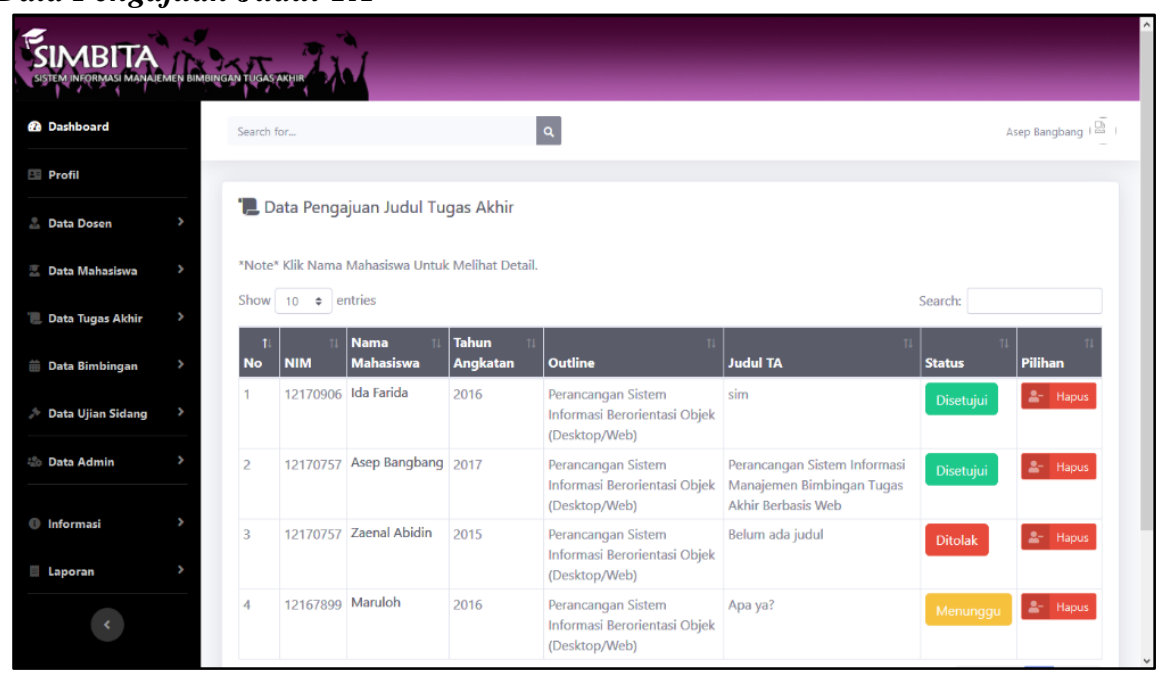

Figure 3.9 Menu Data Pengajuan Judul TA

\subsubsection{Main Menu Mahasiswa}

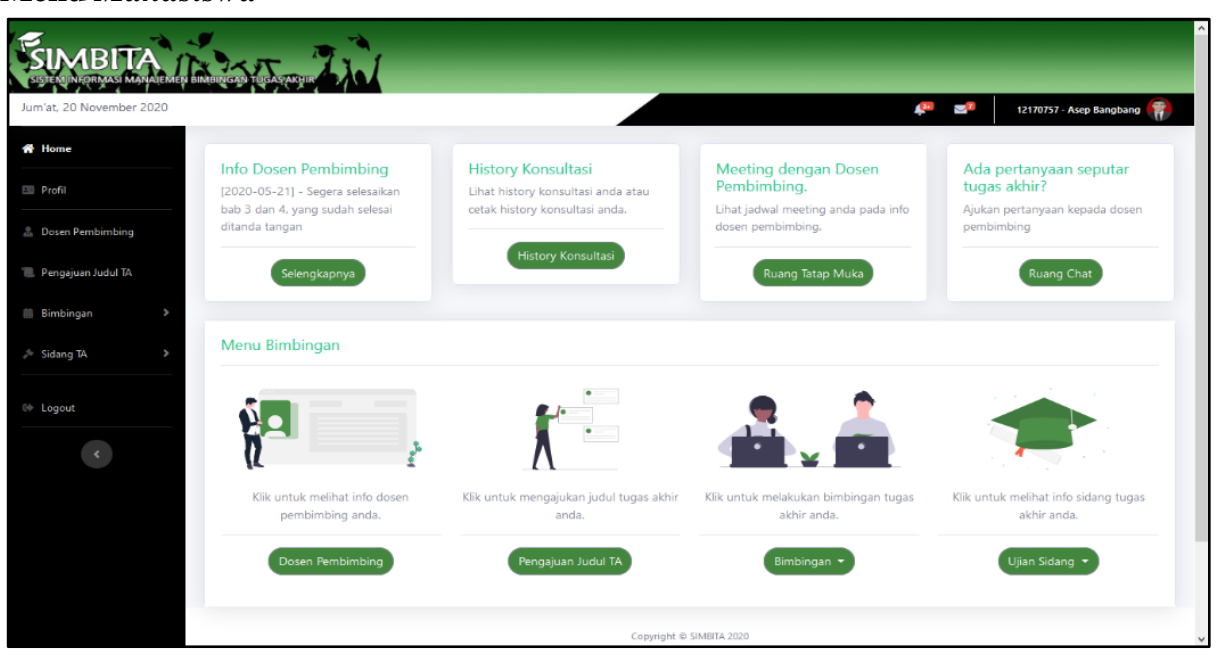

Figure 3.10 Menu Utama Mahasiswa 


\section{Conclusion.}

As the essence of the above writing, several conclusions can be conclude:

1. The running system which is applied in the guidance process of the final project still uses a manual system so it is less efficient because there are frequent obstacles that can hinder the guidance process and the preparation of students' final assignments process.

2. The computerized system is expected to be able to solve the problems in the final assignment guidance system, so it can optimize the guidance process and minimize the error occurs.

3. Implementation of web-based final project guidance management system is expected to facilitate the guidance process, save time, effort, and costs than manual systems.

\section{Acknowledgments}

The author would like say thanks to IT team and fellow lecturers who gave a lot of contribution in writing this paper, so that this paper has been successfully completed.

\section{References.}

[1] Noviana, E., Kurniawan, O., \& Huda, M. N. (2018). Pengembangan Aplikasi Bimbingan Tugas Akhir Mahasiswa Berbasis Website Pada Program Studi Pendidikan Guru Sekolah Dasar Fkip Universitas Riau. Jurnal Primary Program Studi Pendidikan Guru Sekolah Dasar Fakultas Keguruan Dan Ilmu Pendidikan Universitas Riau, 7(April), 1-12. Retrieved from https://primary.ejournal.unri.ac.id/index.php/JPFKIP/article/download/5334/5002

[2] Sari, A., Ugiarto, M., \& Masnawati. (2017). Sistem Informasi Bimbingan Tugas Akhir Pada Fakultas Ilmu Komputer Dan Teknologi Informasi Universitas Mulawarman. Prosiding Seminar Ilmu Komputer Dan Teknologi Informasi, 2(1), 242-249. https://doi.org/10.1016/j.bmcl.2006.11.036

[3] Uno, H. B., \& Ma'ruf, A. R. (2016). Pengembangan Media Pembelajaran IPS Berbasis Website untuk Siswa Kelas VII Madrasah Tsanawiyah Negeri. Jurnal Teknologi Pendidikan, 18(3), 169-185. Retrieved from http://journal.unj.ac.id/unj/index.php/jtp/article/view/5372/3994

[4] Januarisman, E., \& Ghufron, A. (2016). Pengembangan Media Pembelajaran Berbasis Web Mata Pelajaran Ilmu Pengetahuan Alam Untuk Siswa Kelas VII. Jurnal Inovasi Teknologi Pendidikan, 3(2), 166. https://doi.org/10.21831/jitp.v3i2.8019

[5] Nurahman, D., Prasetyo, F. H., \& Agustina, B. (2018). Rancang Bangun Sistem Informasi Akuntansi Pendapatan Jasa Atas Pasien Rawat Inap Pada Klinik Azimat Karawang. Jurnal Inovasi Informatika, III(11), 281-289. Retrieved from http://www.jurnalpradita.com/index.php/jii/article/view/56/42

[6] Lestari, M. A., Tabrani, M., \& Ayumida, S. (2018). Sistem Informasi Pengolahan Data Administrasi Kependudukan Pada Kantor Desa Pucung Karawang. Jurnal Interkom Vol. 13 No. 3, 13(3), 14-21. Retrieved from https://ejournal.rosma.ac.id/index.php/interkom/article/view/30

[7] Saputra, R. D., \& Musyofa. (2017). Sistem Informasi Pembelian Bahan Baku Berbasis Client Server Pada PT.Japfa Comfeed Indonesia Tbk. Jurnal Cendikia, 14(1), 33-41

[8] Ibrahim, A. (2016). Analisis Implementasi Manajemen Kualitas Dari Kinerja Operasional Pada Industri Ekstraktif Di Sulawesi Utara. Jurnal EMBA, 4(2), 859-869. Retrieved from https://ejournal.unsrat.ac.id/index.php/emba/article/view/13279/12864

[9] Noviana, E., Kurniawan, O., \& Huda, M. N. (2018). Pengembangan Aplikasi Bimbingan Tugas Akhir Mahasiswa Berbasis Website Pada Program Studi Pendidikan Guru Sekolah Dasar Fkip Universitas Riau. Jurnal Primary Program Studi Pendidikan Guru Sekolah Dasar Fakultas Keguruan Dan Ilmu Pendidikan Universitas Riau, 7(April), 1-12. Retrieved from https://primary.ejournal.unri.ac.id/index.php/JPFKIP/article/download/5334/5002

[10] Seprina, I., \& Sobri, M. (2016). Perancangan Aplikasi Pengolahan Data Administrasi Tugas Akhir Mahasiswa Berbasis Web. Jurnal INFORMANIKA, 2(2), 1-11. Retrieved from http://eprints.binadarma.ac.id/3122/

[11] A.S., Rosa dan Shalahuddin, M. 2015. Rekayasa Perangkat Lunak Terstruktur dan Berorientasi Objek.Bandung: Informatika Bandung..

[12] Kurniawan, T. A. (2018). Pemodelan Use Case (UML): Evaluasi Terhadap beberapa Kesalahan dalam Praktik. Jurnal Teknologi Informasi Dan Ilmu Komputer, 5(1), 77. https://doi.org/10.25126/jtiik.201851610

[13] Suendri. (2018). Implementasi Diagram UML (Unified Modelling Language) Pada Perancangan Sistem Informasi Remunerasi Dosen Dengan Database Oracle (Studi Kasus: UIN Sumatera Utara Medan). Jurnal Ilmu Komputer Dan Informatika, 3(1), 1-9. Retrieved from http://jurnal.uinsu.ac.id/index.php/algoritma/article/download/3148/1871

[14] Kevin, F., Sumantri, R., Wowor, H. F., \& Lumenta, A. S. M. (2016). Sistem Informasi Anggota Jemaat Gmim Bethesda Ranotana Menggunakan Framework Codeigniter. Jurnal Teknik Elektro Dan Komputer, 5(2), 21-28.

[15] Brady, M., \& Loonam, J. (2010). Exploring the use of entity $\square$ relationship diagramming as a technique to support grounded theory inquiry. Qualitative Research in Organizations and Management: An International Journal, 5(3), 224-237. https://doi.org/10.1108/17465641011089854 